
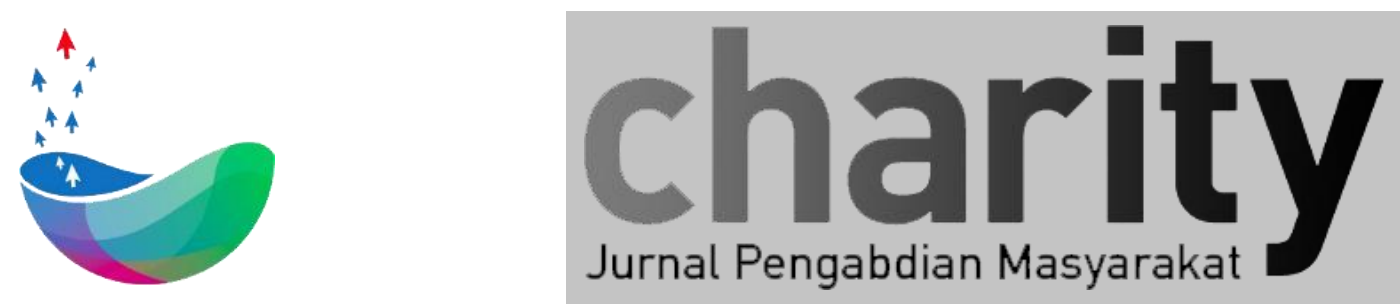

\title{
Pembuatan Prototipe Alat Pencucian Galon serta Pelatihan Sistem Kerja dan Pemeliharaannya di CV Barokah Abadi Baleendah Bandung
}

\author{
Husni Amani ${ }^{1}$, Agus Kusnayat ${ }^{2}$, Dida Diah Damayanti ${ }^{3}$, Fransiskus Tatas Dwi Atmaji ${ }^{4}$ \\ 1,2,3,4 Program Studi Teknik Industri, Fakultas Rekayasa Industri, Universitas Telkom \\ husni@telkomuniversity.ac.id, guskus@ @elkomuniversity.ac.id, didadiah@telkomuniversity.ac.id, franstatas@telkomuniversity.ac.id
}

\section{INFO ARTIKEL}

Diterima 19 Maret 2019

Direvisi 26 Maret 2019

Disetujui 30 Agustus 2019

Tersedia Online 6 Juli 2020

\begin{abstract}
ABSTRAK
Proses pencucian galon oleh CV. Barokah Abadi Baleendah saat ini masih belum optimal karena masih dilakukan secara manual. Selain itu, prosesnya masih membutuhkan beberapa kegiatan yang terpisah menggunakan sarana yang berbeda baik untuk pencucian maupun untuk proses pembilasan galon. Akibatnya proses pencucian galon memerlukan tempat yang relatif luas dan membutuhkan waktu proses pencucian yang relatif lama. Paper ini bertujuan untuk membuat sebuah prototipe alat bantu pencucian galon agar proses pencucian galon menjadi lebih efektif dan efisien. Perancangan awal alat pencuci galon menggunakan pendekatan reverse engineering and redesign methodology serta mempertimbangkan dari sisi ergonomic factor. Alat ini didisain dengan menyatukan beberapa proses yang ada menjadi satu proses ditempat yang sama. Disain alat menyesuaikan user experience operator sehingga dapat memudahkan penggunaannya. Dari data, perancangan alat telah menghasilkan sebuah alat pencucian galon dengan kendali PLC mencapai rata-rata waktu mencapai rata-rata waktu 31,07 detik. Hasil ini jauh lebih bagus dari rata-rata proses pencucian galon secara manual sebelumnya yang mencapai waktu 95,93 detik Hasil ini telah meningkatkan produktivitas pencucian galon, dengan peningkatan sebesar $68 \%$ dari proses pencucian eksisting sebelumnya.
\end{abstract}

Keyword: alat pencuci galon, ergonomic factor, reverse engineering, redesign methodology

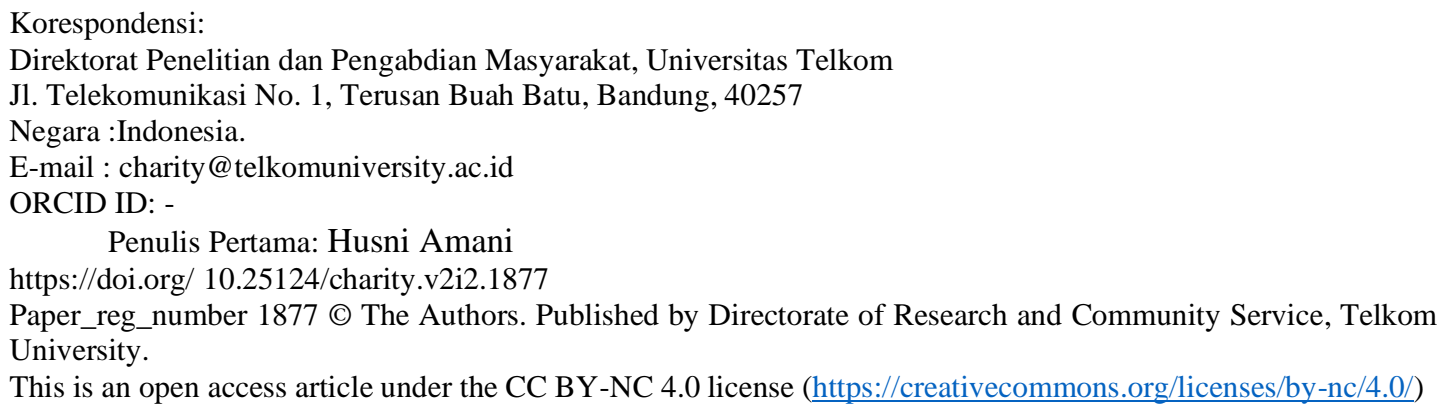




\section{Pendahuluan}

Kebutuhan akan air, khususnya air minum semakin bertambah seiring dengan bertambahnya jumlah penduduk. Untuk mendapatkan air minum yang layak dikonsumsi, salah satunya adalah dengan menggunakan air minum dalam kemasan (AMDK). Kebutuhan akan air minum yang praktis dan sehat menjadi pilihan masyarakat modern saat ini, khususnya di wilayah perkotaan dan daerah urban. Berbagai pilihan kemasan dalam AMDK ditawarkan, dari model kemasan gelas sampai kemasan galon. Air minum dalam kemasan galon juga menjadi pilihan yang cukup untuk memenuhi kebutuhan harian atau keperluan rumah tangga yang lain. Dengan adanya kemasan dalam galon ini, akhirnya munculah depo-depo pengisian air minum dalam kemasan galon. Dari sisi harga, air isi ulang galon lebih murah dari air galon produksi pabrikan resmi. Namun disisi lain, kualitas air minum ini diragukan karena diduga ada kontaminasi dari bakteri pathogen dan yang lain jika sistem pengisian atau kebersihan depo pengisian air galon ini kurang diperhatikan.

Berdasarkan studi kasus Yayasan Lembaga Konsumen Indonesia (YLKI) terdapat 20 depo air minum isi ulang di wilayah Jakarta yang tidak memenuhi standar pengisian air minum, seperti tidak adanya proses sterilisasi pada galon air [1]. Proses produksi yang tidak memenuhi standar diduga menjadi faktor penyebab produk tersebut tercemar. Selain itu, penanganan produk secara tidak tepat saat distribusi hingga sampai ke pedagang dan konsumen juga berpengaruh pada kualitas Air Minum Dalam Kemasan (AMDK). Pencucian kemasan yang tidak tepat dan menyeluruh dapat mempengaruhi kualitas air mineral yang dikemas dan dapat memicu perkembangan mikroba pada bagian dalam kemasan.

Mengacu pada standar World Health Organization (WHO), Kementerian Kesehatan RI telah menetapkan kriteria kualitas air secara mikrobiologis, melalui Peraturan Menteri Kesehatan No.492/Menkes/Per/IV/2010 [2], bahwa parameter mikrobiologi untuk Escherichia Coli dan Total Bakteri Koliform, kadar maksimum yang diperbolehkan per $100 \mathrm{ml}$ sampel adalah 0 (Tidak boleh mengandung E.Coli dan Coliform setiap $100 \mathrm{ml}$ sampel). Sedangkan Badan Standarisasi Nasional menerapkan Standar Nasional Indonesia (SNI) No.01-3553-2006 tentang AMDK [3] mensyaratkan bahwa jumlah cemaran mikroba pada angka lempeng total awal maksimal 1,0x 102 koloni/ml saat di pabrik dan angka lempeng total akhir 1,0x $105 \mathrm{koloni} / \mathrm{ml}$ saat sudah di pasaran. Untuk bakteri berbentuk Coli batas maksimalnya adalah < 2 APM/100 ml dan tidak boleh mengandung bakteri pathogen yaitu Salmonella dan Pseudomonas Aeruginosa.

CV. Barokah Abadi merupakan sebuah salah satu perusahaan yang bergerak dalam bidang produksi air minum kemasan yang berlokasi didaerah Baleendah, Kabupaten Bandung, Jawa Barat. Dalam proses produksi, dilakukan proses pengisian air minum ke dalam galon, disamping melakukan proses pencucian galon yang akan dipakai untuk tempat air minum. Proses pencucian galon oleh CV. Barokah Abadi Baleendah saat ini masih belum optimal karena masih dilakukan secara manual. Akibatnya proses pencucian galon memerlukan tempat yang relatif luas dan membutuhkan waktu proses pencucian yang relatif lama. Untuk itu paper ini bertujuan untuk memberikan usulan desain dan menjelaskan tentang pembuatan prototipe alat pencuciaan galon. Secara umum, perancangan awal alat pencuci galon ini akan menggunakan pendekatan reverse engineering and redesign methodology dengan mempertimbangkan dari sisi ergonomic factor juga.

Paper ini terdiri dari atas beberapa bab:bab 2 menjelaskan lebih rinci tentang permasalahan yang terjadi, dilanjutkan bab 3 menjelaskan tentang metode 
pelaksanaan. Bab 4 menjelaskan tentang hasil dari perancangan dan uji coba dari prototipe, kemudian di tutup dengan kesimpulan dan saran di bab 5.

\section{Permasalahan Utama}

Dalam proses penanganan dan pencucian galon, tahapan yang dilakukan oleh CV. Barokah Abadi Baleendah, diawali dengan melakukan pembersihan galon terlebih dahulu dengan cara mencuci galon sebelum melakukan pengisian ulang air minum. Melihat kondisi alat yang ada, terdapat beberapa kekurangan pada sistem yang dijalankan saat ini yaitu produktivitas yang relative rendah disebabkan oleh penanganan yang kurang profesional termasuk kebersihan pada galon sehingga kualitas air yang tersimpan didalam galon dapat terkontaminasi oleh bakteri pathogen. Pada kondisi existing bagian pencucian terdiri atas empat tahapan yang 70\% prosesnya masih dilakukan secara manual diantaranya seperti pencucian bagian luar galon dalam sebuah bak penampungan air seluas 2,25 $\mathrm{m}^{2}$ dengan menggunakan cairan deterjen dan penggosok spons serta sikat untuk membersihkan bagian luar galon dari kotoran, selanjutnya galon yang sudah bersih dipindahkan ke dalam bak penampungan air berisi air bersih tanpa deterjen dengan luas yang sama untuk membilas bagian luar galon dari sisa busa deterjen. Proses selanjutnya adalah membersihkan bagian dalam galon, dengan cara disemprot oleh air bertekanan tinggi dengan menggunakan selang khusus, apabila masih ada noda yang masih menempel, selanjutnya bagian dalam galon akan dibersihkan dengan cara digosok dengan mesin khusus kemudian disemprot kembali dengan menggunakan selang.

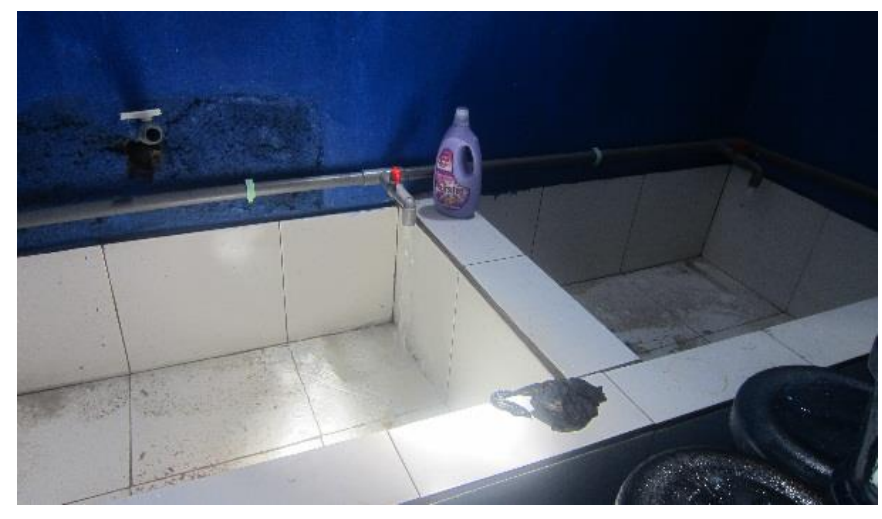

Gambar 1 Kondisi bak pencucian untuk bagian luar galon

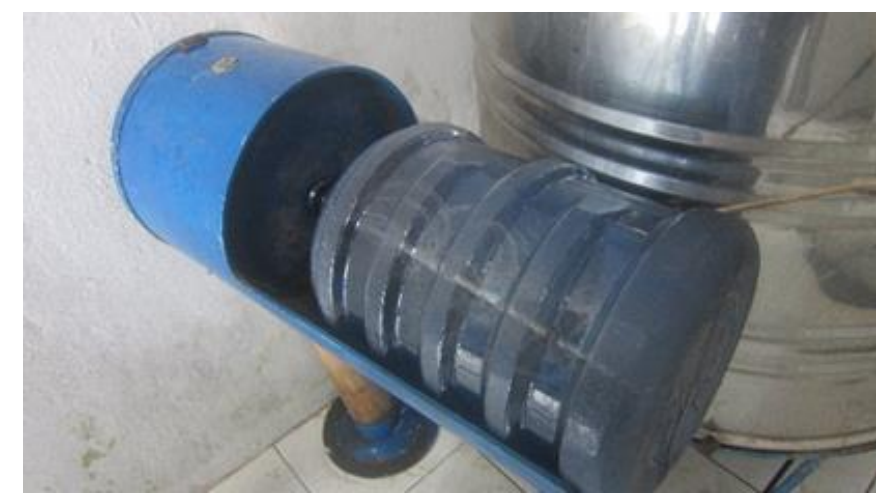

Gambar 2 Proses pembersihan galon bagian dalam dengan menggunakan mesin khusus 


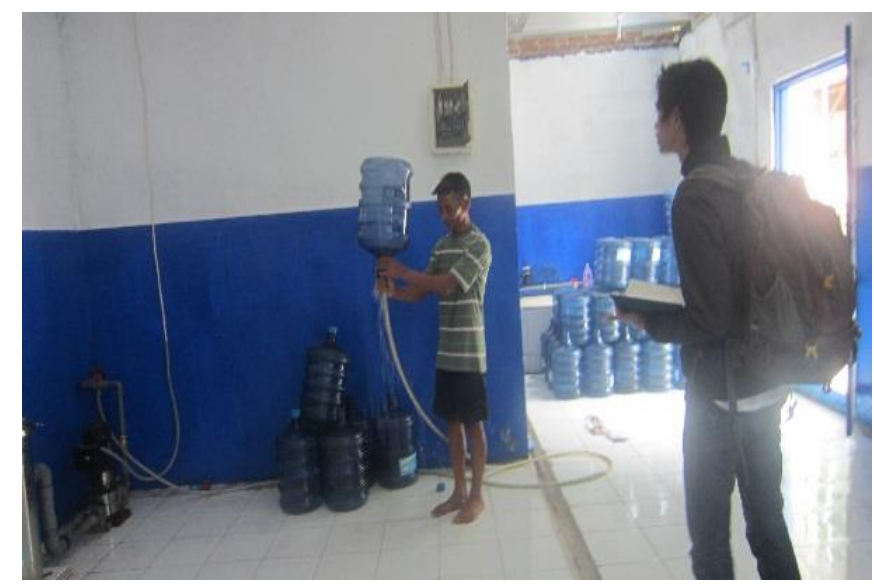

Gambar 3 Kondisi penyemprotan galon bagian dalam dengan selang bertekanan sedang

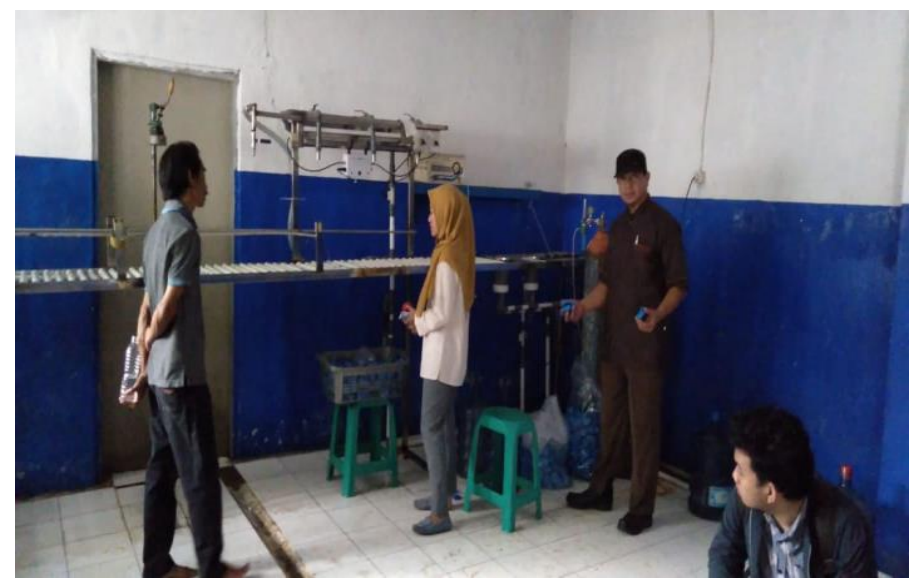

Gambar 4 Kondisi ruangan dan alat pengisian galon eksisting

Dari gambar 1 sampai dengan gambar 4 menunjukkan bahwa proses pencucian dan pengisian galon di CV Barokah Abadi yang masih membutuhkan beberapa kegiatan terpisah dan menggunakan sarana yang berbeda, baik untuk pencucian maupun untuk proses pembilasan galon. Akibatnya proses pencucian galon memerlukan tempat yang relatif luas dan membutuhkan waktu proses pencucian yang relatif lama. Untuk alur proses pengisian air galon dari awal sampai akhir akan di jelaskan di diagram gambar 5 berikut ini. 


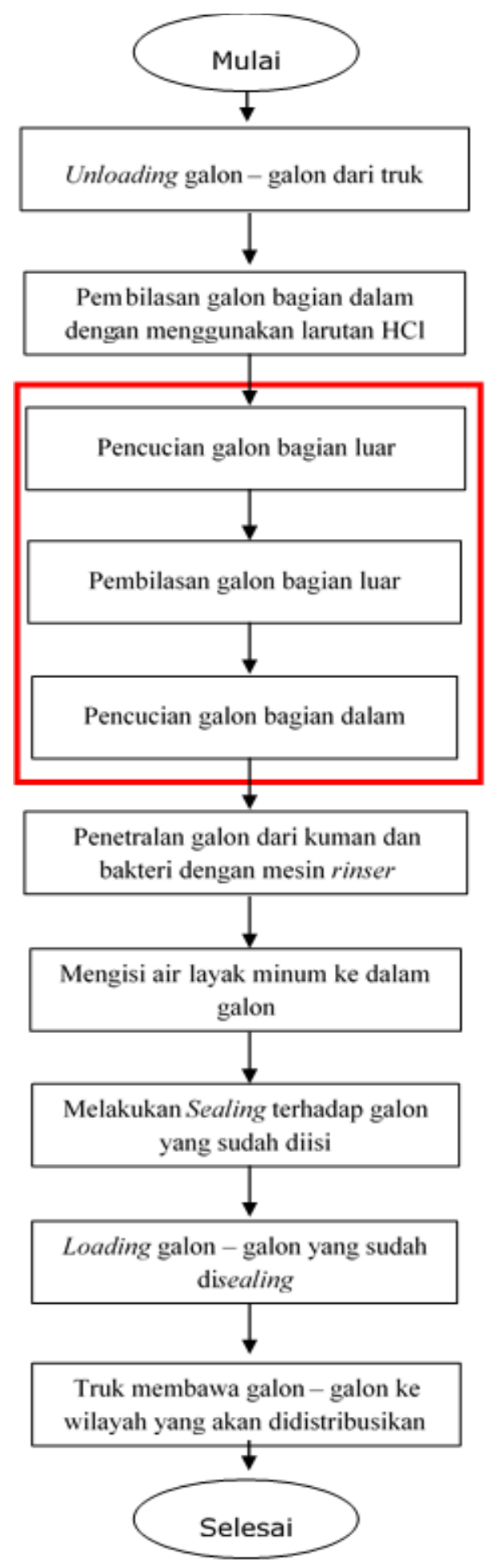

\section{Gambar 5 Urutan proses pengisian air minum}

Dari gambar 5 dapat dijelaskan urutan proses dari awal sampai akhir proses pengisian air galon. Perlu ditekankan bahwa yang akan menjadi fokus dalam paper ini adalah permasalahan yang ada pada bagian dalam yang dibuat garis warna merah, yaitu proses pencucian dan pembilasan galon bagian luar dan dalam di CV Barokah Abadi. Berdasarkan informasi dan wawancara dengan operator pencuci galon, operator melakukan pencucian galon sebanyak kurang lebih 800 galon per hari, dengan 
posisi jongkok. Hal tersebut dapat menyebabkan kelelahan atau bahkan cedera otot. Postur kerja dengan posisi jongkok bukan postur kerja yang ideal untuk melakukan suatu pekerjaan [4]-[7]. Paper ini bertujuan untuk membuat sebuah prototipe alat bantu pencucian galon agar proses pencucian galon menjadi nyaman, lebih efektif dan efisien.

\section{Metode dan analisa pemecahan masalah}

Dalam pembuatan prototipe alat bantu pencucian galon ini, langkah awal adalah memetakan sebuah alur solusi yang ditawarkan untuk mengatasi permasalahan yang ada berdasarkan analisa faktor ergonomi [8]-[11] dan metode Reverse Engineering and Redesign Methodology [12]

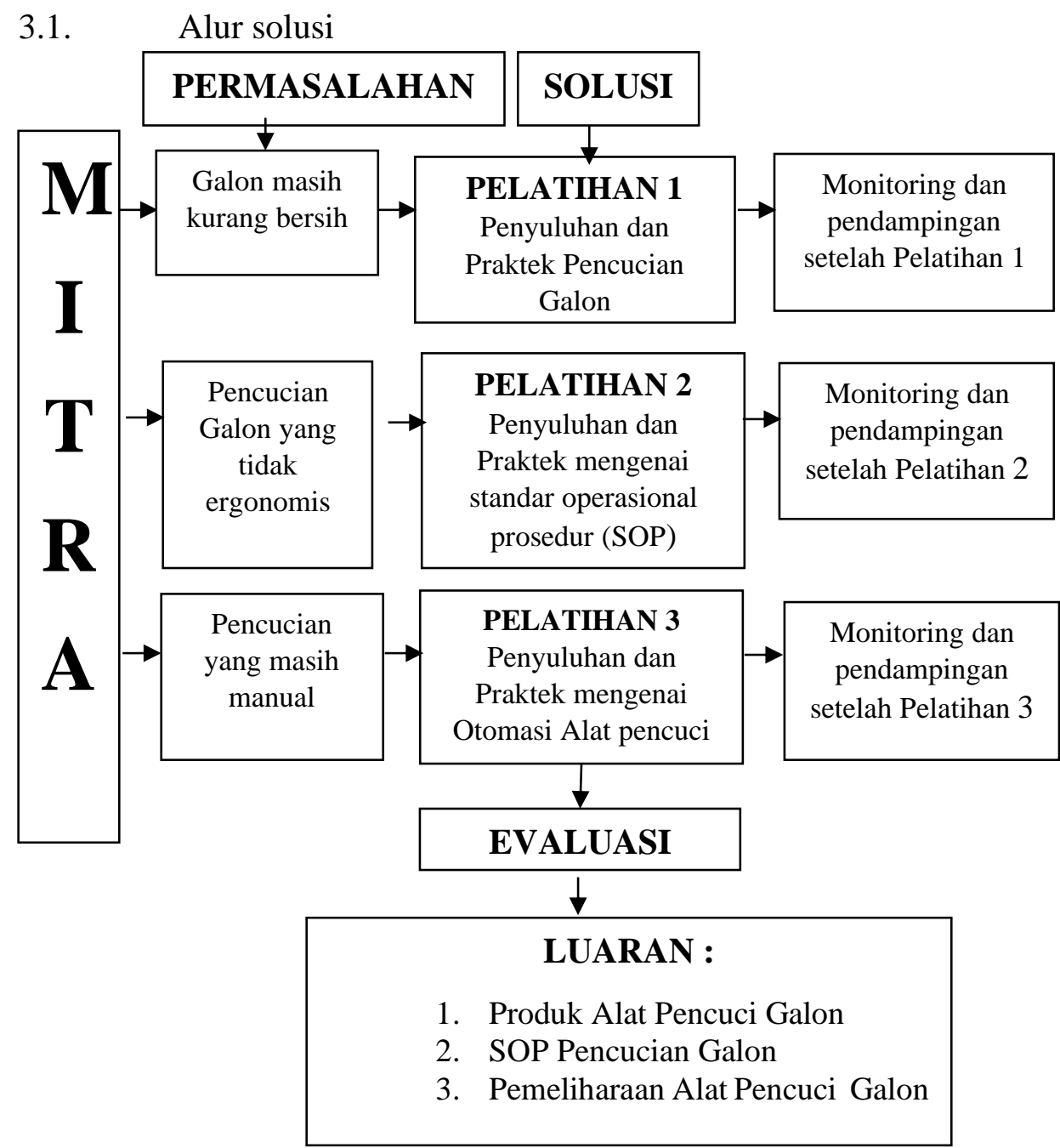

Gambar 6. Alur solusi yang ditawarkan

\subsection{Analisa faktor Ergonomi}

Berdasarkan kondisi existing, terdapat tiga postur tubuh yang perlu dianalisis, diantaranya adalah posisi tubuh disaat melakukan pencucian bagian luar galon, penyemprotan dan penyikatan bagian dalam galon. Analisis dilakukan dengan metode Rapid Upper Limb Assesment (RULA) [8] yakni dengan menggunakan aplikasi 
berbasis virtual environment pada pengamatan manequin populasi Cina seperti yang dapat dilihat pada tabel 1. Berdasarkan penelitian Antropometry of the Singaporean and Indonesian Popupations bahwa postur tubuh populasi orang Indonesia memiliki kesamaan dengan postur etnis Cina dengan tingkat persentil 50\% [9].

Tabel 1 Hasil RULA Software Jack [10]

\begin{tabular}{|l|c|l|}
\hline \multicolumn{1}{|c|}{ Nama Aktivitas } & $\begin{array}{c}\text { Skor } \\
\text { RULA }\end{array}$ & \multicolumn{1}{|c|}{ Analisis Tindakan } \\
\hline $\begin{array}{l}\text { Pencucian dan } \\
\text { Pembilasan bagian luar } \\
\text { Galon }\end{array}$ & 7 & $\begin{array}{l}\text { Postur berisiko tinggi, perbaikan harus } \\
\text { dilakukan saat ini juga. }\end{array}$ \\
\hline $\begin{array}{l}\text { Penyemprotan bagian } \\
\text { dalam Galon }\end{array}$ & 5 & $\begin{array}{l}\text { Postur berisiko menengah, perbaikan } \\
\text { dilakukan sesegera mungkin. }\end{array}$ \\
\hline $\begin{array}{l}\text { Penggosokan bagian } \\
\text { dalam Galon }\end{array}$ & 6 & $\begin{array}{l}\text { Postur berisiko menengah, perbaikan } \\
\text { dilakukan sesegera mungkin. }\end{array}$ \\
\hline
\end{tabular}

Berdasarkan pengukuran Rapid Upper Limb Assesment terhadap ketiga aktivitas pencucian, dengan melihat nilai skor dapat disimpulkan bahwa pada proses pencucian galon di CV Barokah Abadi cenderung melibatkan postur tubuh canggung yang akan mengakibatkan terjadinya Musculoskeletal Disorders (MSDs) pada pekerja apabila pekerjaan dilakukan secara berulang. Berdasarkan hasil studi pendahuluan yang dilakukan terhadap 4 (empat) orang pekerja dengan melakukan penyebaran kuesioner Nordic Body Map (NBM) terkait keluhan kesehatan yang dialami selama melakukan pekerjaan pencucian, didapatkan bahwa 100\% responden mengalami Musculoskeletal Disorders (MSDs) setelah bekerja dengan enam peringkat keluhan terbesar seperti yang dapat dilihat pada tabel 2.

Tabel 2 Perhitungan Kuesioner Nordic Body Map (NBM) [10]

\begin{tabular}{|l|c|}
\hline \multicolumn{1}{|c|}{ Kelelahan Dominan } & Besar Keluhan \\
\hline Sakit di punggung & $88 \%$ \\
\hline Sakit pada lengan atas kanan & $88 \%$ \\
\hline Sakit pada lengan bawah kanan & $88 \%$ \\
\hline Sakit pada pergelangan tangan kanan & $88 \%$ \\
\hline Sakit pada pinggang & $81 \%$ \\
\hline
\end{tabular}

Rasa sakit yang dialami pekerja didukung oleh kondisi dan beban pekerjaan yang cukup berat, diantaranya seperti kondisi dimana pekerja harus memegang galon dengan satu tangan sedangkan tangan lainnya menyemprot bagian dalam galon, kondisi tersebut mendukung kelelahan otot lengan atas, bawah, tangan dan pergelangan tangan sekaligus karena mulut galon harus berada pada posisi mengarah 
kebawah sehingga pekerja harus menahan galon terus menerus secara berulang. Rasa sakit dari Musculoskeletal Disorders pada pekerjaan tentunya dapat menyebabkan ketidaknyamanan bagi pekerja. Hal tersebut dapat memicu hal-hal seperti stres, penurunan produktivitas dan kepuasan kerja bahkan kesulitan dalam beraktivitas diluar pekerjaan sekalipun [11]. Oleh karena itu paper ini akan mencoba fokus membuat desain alat cuci galon semi otomatis untuk mempercepat proses pekerjaan yang memenuhi aspek aspek ergonomic untuk membantu mengurangi resiko cedera yang mungkin akan dialami oleh pekerja.

\subsection{Desain alat dengan Reverse Engineering and Redesign Methodology}

Perancangan awal alat pencuci galon ini menggunakan pendekatan reverse engineering and redesign methodology. Reverse Engineering and Redesign Methodology adalah metode yang intinya membahas pada tahapan proses yang dibutuhkan untuk memahami dan menggambarkan produk eksisting sebelumnya [12]. Pembahasan utama reverse engineering adalah melakukan produksi ulang obyek yang sudah ada dengan menganalisis dimensi, fitur, bentuk dan sifat sehingga data dan informasi yang dikumpulkan harus diubah menjadi pengetahuan produk yang berkaitan di tingkat sistem, perwujudan, dan detail [13]-[15]. Berikut adalah framework Reverse Engineering and Redesign Methodology yang digambarkan seperti digambar

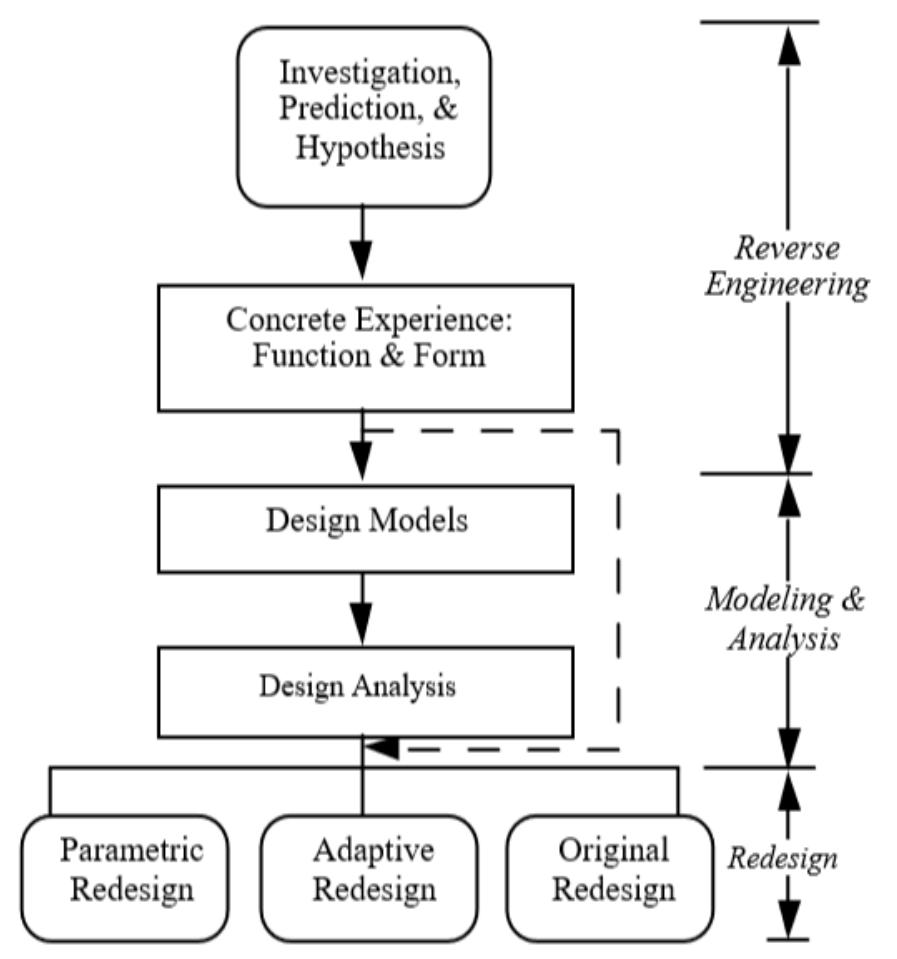

Gambar 7. Reverse Engineering and Redesign Methodology [12]

Reverse Engineering and Redesign Methodology untuk alat pencuci galon terdiri dari tiga tahapan besar, yaitu reverse engineering yang merupakan tahapan untuk melakukan disassembly pada alat pencuci galon terdahulu dan mengidentifikasi kebutuhan user. Kemudian tahap modeling \& analysis yang merupakan tahapan untuk merancang model dari konsep yang telah terpilih sesuai 
dengan spesifikasi teknisnya. Kemudian tahap redesign yang merupakan tahapan untuk melakukan tahapan perancangan ulang terhadap alat pencuci galon eksisting [16]. Dalam perancangan alat pencuci galon ini memerlukan beberapa tahapan pengumpulan data, yaitu: tahapan investigasi, prediksi dan hipotesis melalui kebutuhan user.

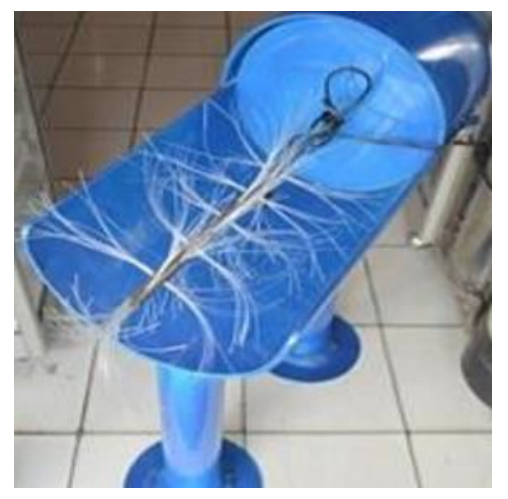

Gambar 8 Desain alat pencuci galon eksisting saat ini [16]

Berdasarkan hasil akhir metode reverse engineering and redesign methodology dan juga analisa dari sisi ergonomi factor, maka terciptalah desain alat pencucian galon seperti di gambar dibawah ini.
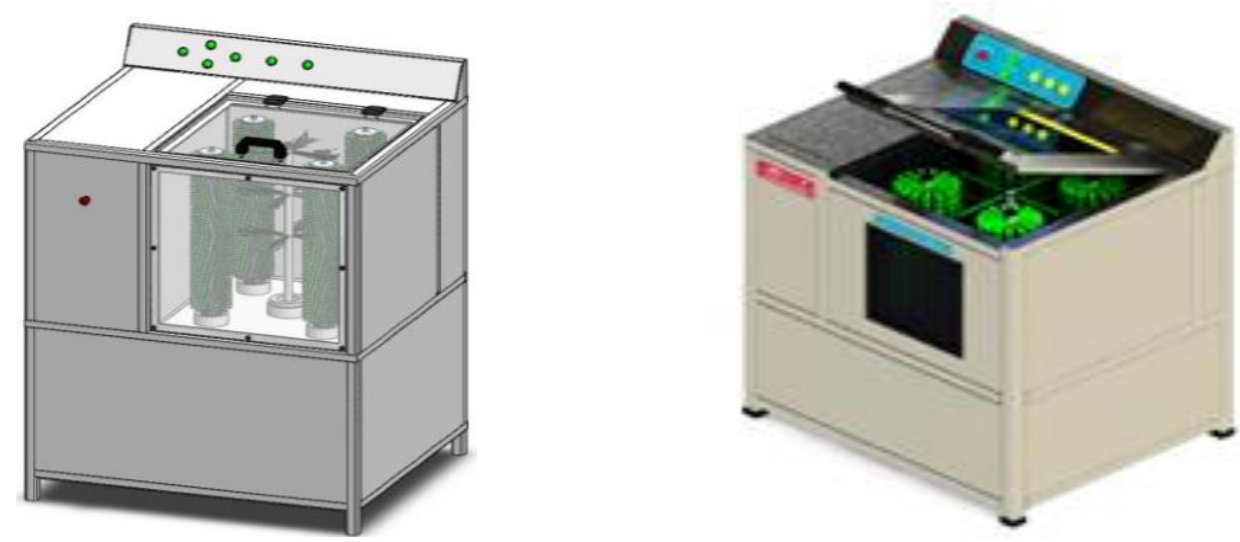

Gambar 9 Desain alat pencuci galon yang akan ditawarkan [10]

Dari gambar desain tersebut secara umum adalah adanya proses penggabungan proses-proses pencucian galon, dari tiga buah proses yang terpisah menjadi satu buah proses yang terintegrasi.

\subsection{Pembuatan prototipe alat pencuci galon}

Alat pencuci galon ini merupakan alat yang dirancang khusus sebagai alat bantu pencucian galon berbasis semi otomasi dengan memperhatikan aspek ergonomi sehingga dapat meningkatkan produktivitas CV. Barokah Abadi, Baleendah. Alat 
Pencuci Galon yang dibuat itu sendiri mengacu pada alat pembersih galon yang sudah ada, dengan inovasi di desain dan sistem kerjanya . Secara umum, ada 3 proses utama dari alat pencucian galon, yaitu: proses pencucian bagian dalam, proses pencucian bagian luar, proses pembilasan. Beberapa perubahan dan inovasi diterapkan dalam pembuatan alat yang pencuci galon yang baru ini, seperti sistem mekanisme penggerak dengan pully dan belt, sistem otomasi dengan menggunakan PLC, push button, dan photo sensor [16], [17], [18], [19], [20]. Dalam proses pembuatan alat pencuci galon dilakukan beberapa tahapan, dari proses survey ke lapangan, dilanjutkan dengan proses perancangan alat dan diskusi dengan tempat fabrikasi alat tersebut, pembuatan alat, sampai proses akhir pengetesan alat. Proses, tahapan dan dokumentasi pembuatan prototipe alat pencuci galon akan di jelaskan dalam lampiran 1.

\section{Hasil dan Analisa waktu pencucian galon}

Dari hasil rancangan alat yang berhasil dibuat, dilakukan percobaan dengan mengambil jumlah data pengamatan sebanyak 15 kali dengan syarat sesuai uji kecukupan data dan keseragaman data dengan hasil yang terdapat halaman terlampir. Hasil waktu proses pencucian galon disajikan pada Tabel 3 sebagai berikut:

Tabel 3. Waktu Proses Pencucian Galon

\begin{tabular}{|c|c|c|c|c|c|c|c|c|c|c|c|c|c|c|c|c|}
\hline Data & 1 & 2 & 3 & 4 & 5 & 6 & 7 & 8 & 9 & 10 & 11 & 12 & 13 & 14 & 15 & Avg. \\
\hline Allowance (d) & 1 & 1 & 1 & 1 & 2 & 1 & 1 & 1 & 1 & 1 & 1 & 1 & 1 & 1 & 1 & 1,07 \\
\hline Proses (d) & 30 & 30 & 30 & 30 & 30 & 30 & 30 & 30 & 30 & 30 & 30 & 30 & 30 & 30 & 30 & 30 \\
\hline Total (d) & 31 & 31 & 31 & 31 & 32 & 31 & 31 & 31 & 31 & 31 & 31 & 31 & 31 & 31 & 31 & 31,07 \\
\hline
\end{tabular}

Pada tabel diatas dijelaskan bahwa dalam melakukan pencucian galon dengan menggunakan alat pencuci galon terdapat allowance operator dalam memasukan galon kedalam alat. Pada keterangan tabel menunjukan rata-rata allowance mencapai 1,07 detik. Selanjutnya proses yang dilakukan alat pencucian galon dalam melakukan proses pencucian menunjukan hasil rata-rata waktu yang dibutuhkan selama 30 detik, hal ini berdasar sesuai skenario program yang dibuat. Dari rata-rata keseluruhan menunjukan bahwa dalam melakukan pencucian galon dibutuhkan waktu 31,07 detik. Analisis perbandingan waktu akan disajikan dalam bentuk grafik perbandingan pada gambar 10 sebagai berikut. 


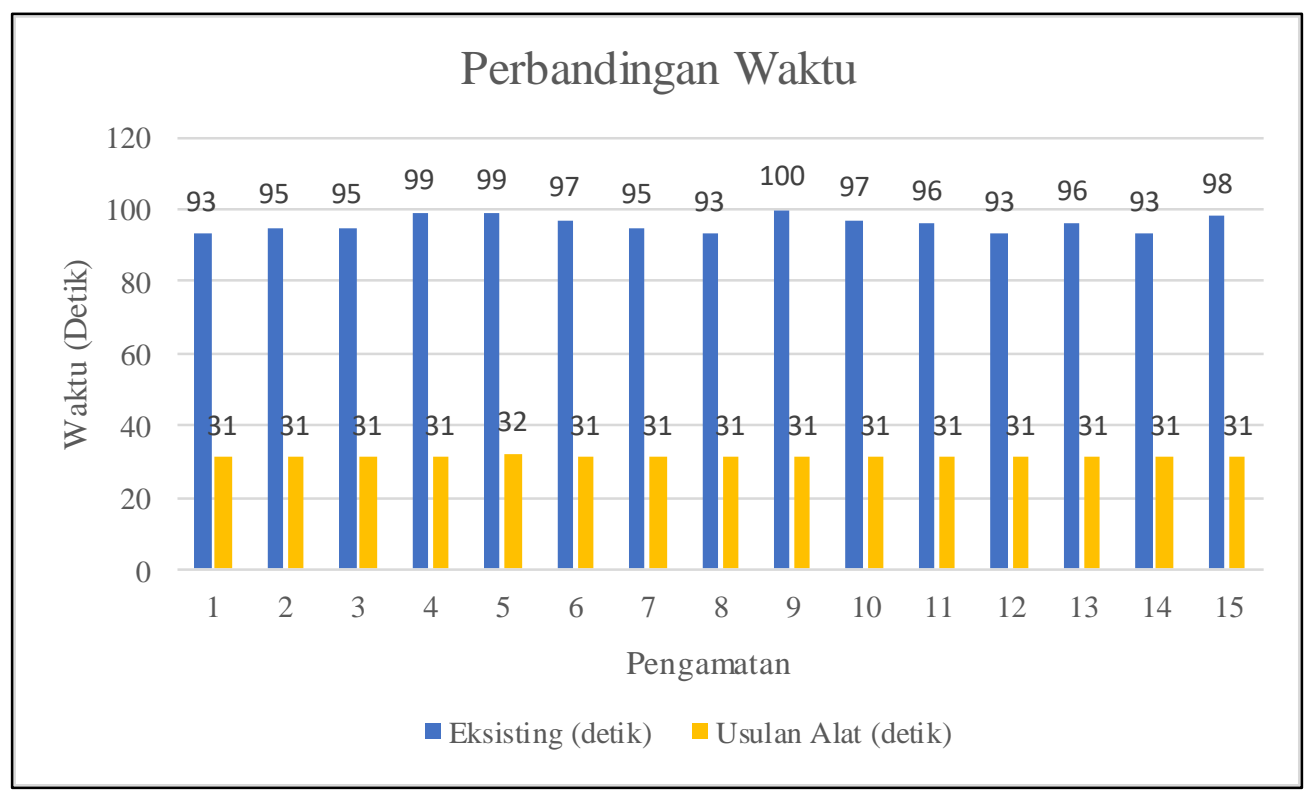

Gambar 10 Grafik perbandingan waktu antara waktu existing (manual) dengan waktu menggunakan alat pencuci galon

Dari grafik gambar 10 tersebut dapat ditarik kesimpulan bahwa waktu eksisting dalam melakukan pencucian galon membutuhkan waktu yang lebih lama jika dibandingkan dengan waktu menggunakan alat pencucian galon. Perbandingan ini mencapai $68 \%$ waktu jauh lebih cepat atau lebih efektif dengan menggunakan alat pencucian galon yang baru dalam melakukan pencucian galon. Dalam hal ini juga menunjukan produktivitas perusahaan bisa meningkat yang diharapkan akan meningkatkan profit perusahaan dalam melakukan bisnis air minum dalam kemasan galon.

\section{Kesimpulan dan Saran}

Makalah atau paper ini bertujuan untuk menjelaskan proses dan latarbelakang pembuatan sebuah prototipe alat bantu pencucian galon agar proses pencucian galon menjadi lebih efektif dan efisien. Perancangan awal alat pencuci galon ini menggunakan pendekatan reverse engineering and redesign methodology. Alat ini didisain dengan menyatukan beberapa proses yang ada menjadi satu proses ditempat yang sama. Disain alat menyesuaikan user experience operator dan ergonomic factor sehingga dapat memudahkan penggunaannya. Alat pencuci galon ini secara umum lebih mudah dan nyaman pada saat dioperasikan dimana alat pencuci galon usulan dioperasikan secara otomatis dan memiliki service ability saat memerlukan pergantian sikat dan yang lain. Dari hasil akhir pengetesan alat, perancangan alat ini telah menghasilkan sebuah alat pencucian galon dengan berbasis kendali PLC denga ratarata waktu pencuaian galon adalah 31,07 detik. Hasil ini jauh lebih bagus dari rata-rata proses pencucian galon secara manual sebelumnya yang mencapai waktu 95,93 detik. Hasil ini menunjukkan produktivitas alat sebesar $68 \%$. Untuk kedepannya, proses pengecekan dan pendataan keandalan dari prototipe pencuci galon ini harus dilakukan untuk mengetahui tingkat reliability alat tersebut sehingga memudahkan untuk proses perbaikan, penyempurnaan atau improvement alat selanjutnya. 


\section{Peryataan dan penghargaan}

Terimakasih kami ucapkan kepada Direktorat Penelitian dan Pengabdian Masyarakat (DPPM) Universitas Telkom yang telah mendanai program penelitian dan kegiatan pengabdian masyarakat ini untuk skema pendanaan kegiatan Pengabdian Kepada Masyarakat Bacth 2 Multiyears, tahun anggaran 2017 dengan Nomor: 261-17/ABD13 /BPM /2017 untuk pendanaan selama 1 tahun, mulai bulan Desember 2017 sd. Desember 2018.

\section{DAFTAR PUSTAKA}

[1] B. Chandra, "Pengantar Kesehatan Lingkungan," Egc, 206AD.

[2] PERMENKES, "Peraturan Menteri Kesehatan Republik Indonesia Nomor 492/Menkes/Per/IV/2010 tentang Persyaratan Kualitas Air Minum," Depkes, 2010 .

[3] Badan Standarisasi Nasional, "Air Minum Dalam Kemasan," Sni 01-35532006, 2006.

[4] T. fuad. Maulana, Sugiharto, and Anizar., "Usulan Perbaikan Fasilitas Kerja Pada Stasiun Pemotongan," e-jurnal Tek. Ind. FT USU Vol 1, No. 2, Maret 2013 pp. 59-63, 2013.

[5] I. Pratiwi and Nurkhasanah, "Evaluasi Musculoskeletal Disorders pada Aktivitas Pembatikan Menggunakan Metode BRIEF Survey," in Simposium nasional Teknologi Terapan (SNTT) 5 2017, 2017.

[6] A. Muchlison, I. Lily Sofwa, and M. Etika, "Perbaikan Metode Kerja Operator Melalui Analisis Musculoskeletal Disorders (MSDs)," in Seminar Nasional IENACO, 2014.

[7] K. Ma'arif, D. Andesta, and S. S. Dahda, "PERANCANGAN ALAT BANTU KERJA PENGELASAN SUPPORT DENGAN REKAYASA NILAI DAN ERGONOMI (STUDI KASUS: PT. PRIMAKARYA JAYA SEJAHTERA)," MATRIK (Jurnal Manaj. dan Tek., 2018.

[8] D. MacLeod, "Rapid Upper Limb Assessment (RULA)," in The Rules of Work, 2013.

[9] T. K. Chuan, M. Hartono, and N. Kumar, "Anthropometry of the Singaporean and Indonesian populations," Int. J. Ind. Ergon., 2010.

[10] Z. Fakhriza, M. Rahayu, and M. Iqbal, "Design improvement of automated galon washing machine to minimize musculoskeletal disorders (MSDs) in CV Barokah Abadi using ergonomic function deployment (EFD) approach," in IOP Conference Series: Materials Science and Engineering, 2017. 
[11] C. Harris-Adamson, S. S. Bao, and B. Evanoff, "Musculoskeletal disorders," in Occupational and Environmental Health, 2017.

[12] K. N. Otto and K. L. Wood, "Product Evolution: A Reverse Engineering and Redesign Methodology," Res. Eng. Des. - Theory, Appl. Concurr. Eng., 1998.

[13] G. Šag, Z. Lulić, and I. Mahalec, "Reverse engineering," in Concurrent Engineering in the 21st Century: Foundations, Developments and Challenges, 2015.

[14] D. Yurichev, Reverse Engineering for Beginners. 2016.

[15] H. A. Muller, J. H. Jahnke, D. B. Smith, and M.-A. Storey, "Reverse engineering: a roadmap," in Proceedings of the Conference on The Future of Software Engineering (ICSE '00), 2000.

[16] A. Yudanto, A. Kusnayat, M. Rahayu, P. Studi, T. Industri, F. R. Industri, and U. Telkom, "PERANCANGAN ALAT PENCUCI GALON MENGGUNAKAN PENDEKATAN REVERSE ENGINEERING \& REDESIGN METHODOLOGY DI CV . BAROKAH ABADI THE DESIGN OF THE APPLIANCE WASH GALON USING REVERSE ENGINEERING APPROACH \& REDESIGN METHODOLOGY IN CV . BAROKAH ABADI," eProceedings Eng. 2018, vol. 5, no. 1, pp. 1208-1213, 2018.

[17] A. E. Putra, "Sistem Kontrol Proses dan PLC," PLC Konsep, 2004.

[18] W. Bolton, “I/O Processing," in Programmable Logic Controllers, 2012.

[19] W. Bolton, "1 - Programmable logic controllers," in Programmable Logic Controllers (Fourth Edition), 2006.

[20] B. M. Wilamowski and J. D. Irwin, "Fundamentals of Industrial Electronics Context," Ind. Electron. Handb. - Second Ed., 2011. 


\section{LAMPIRAN 1}

Dokumentasi proses pembuatan prototipe alat pencuci galon

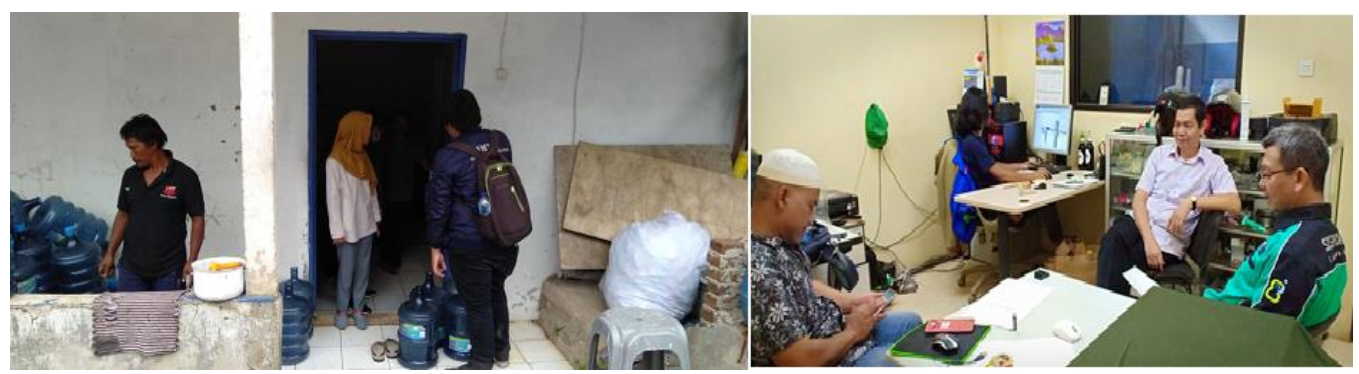

Gambar 1 Proses survey dan diskusi dengan tempat fabrikasi pembuatan alat

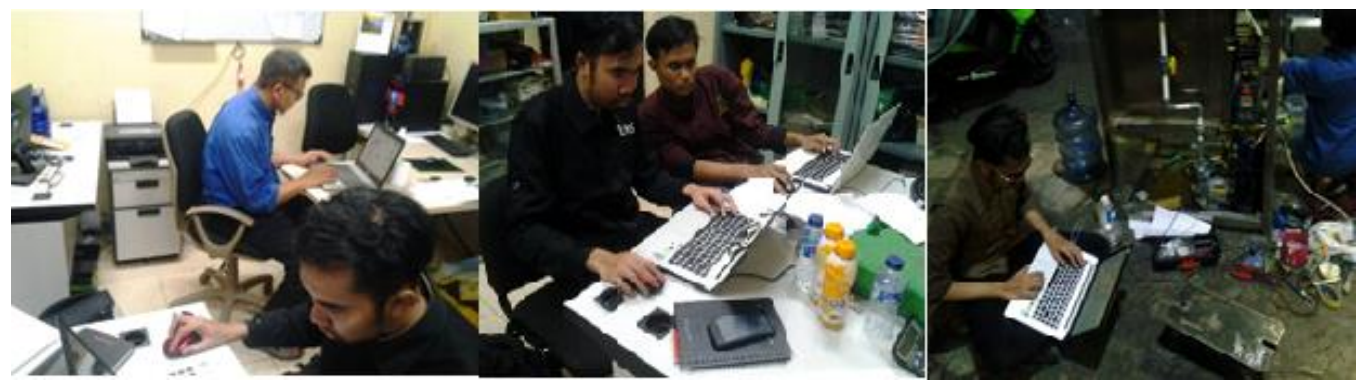

Gambar 2 Proses Pembuatan desain alat

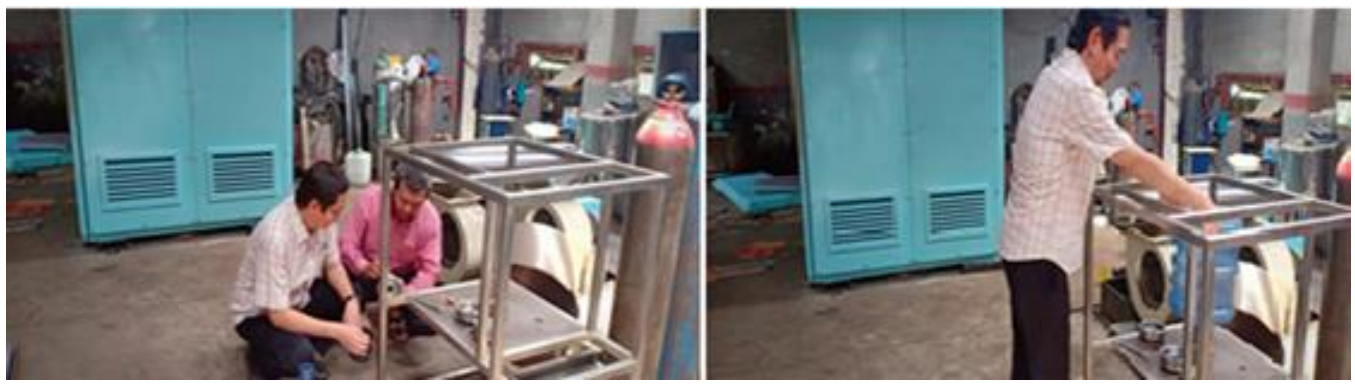

Gambar 3 Pembuatan Rangka Alat Pencuci Galon Semi Otomatis 


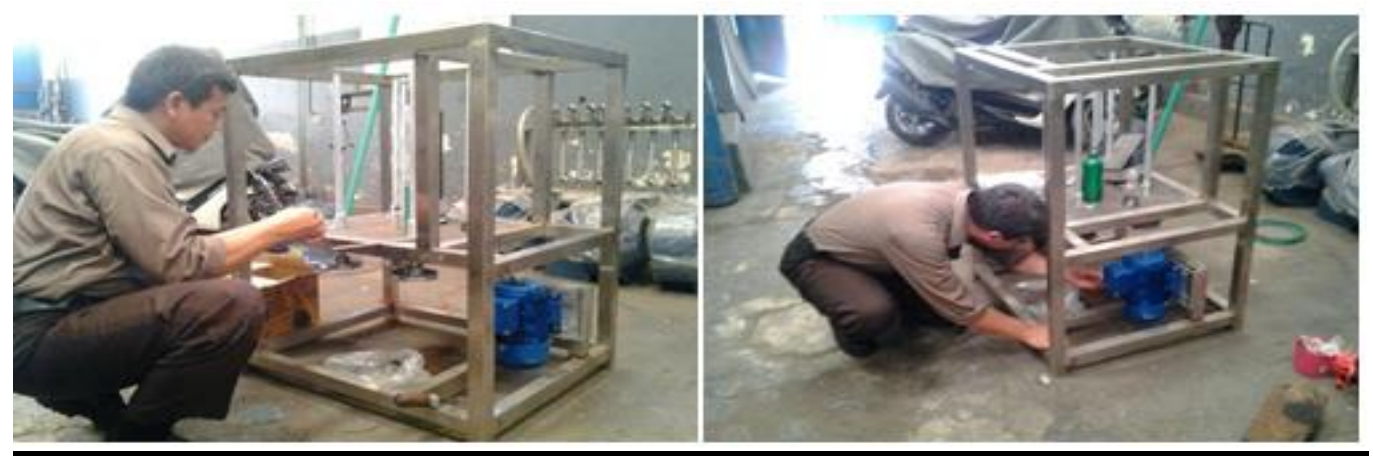

Gambar 4 Pembuatan Rangka Alat Pencuci Galon Semi Otomatis

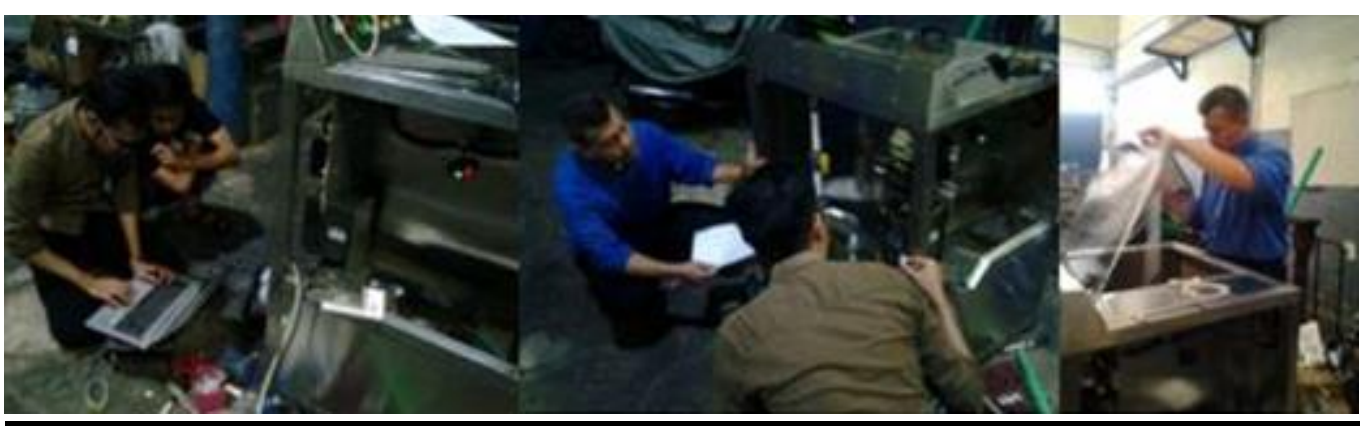

Gambar 5 Sinkronisasi pemprograman dan uji sistem sensor

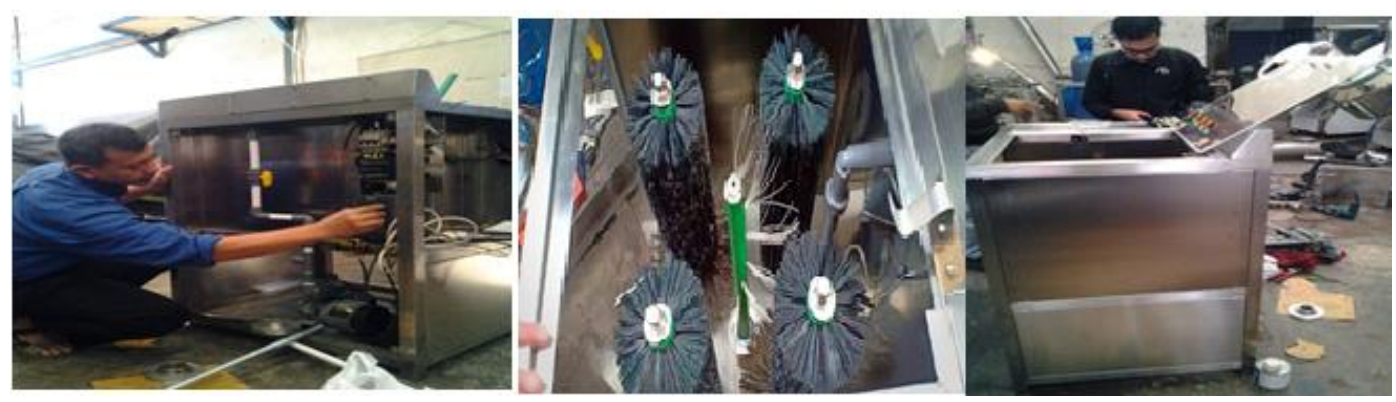

Gambar 6 Proses pengecekan dan pemasangan sikat pembersih

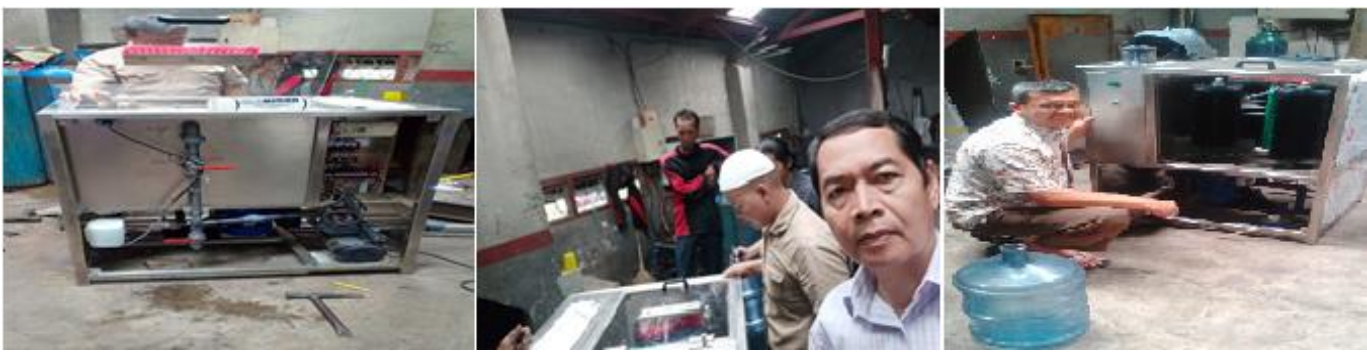

Gambar 7 Proses pengetesan alat pencuci (3 kali test) 


\section{LAMPIRAN 2}

Dokumentasi pelatihan penggunaan alat dan serah terima

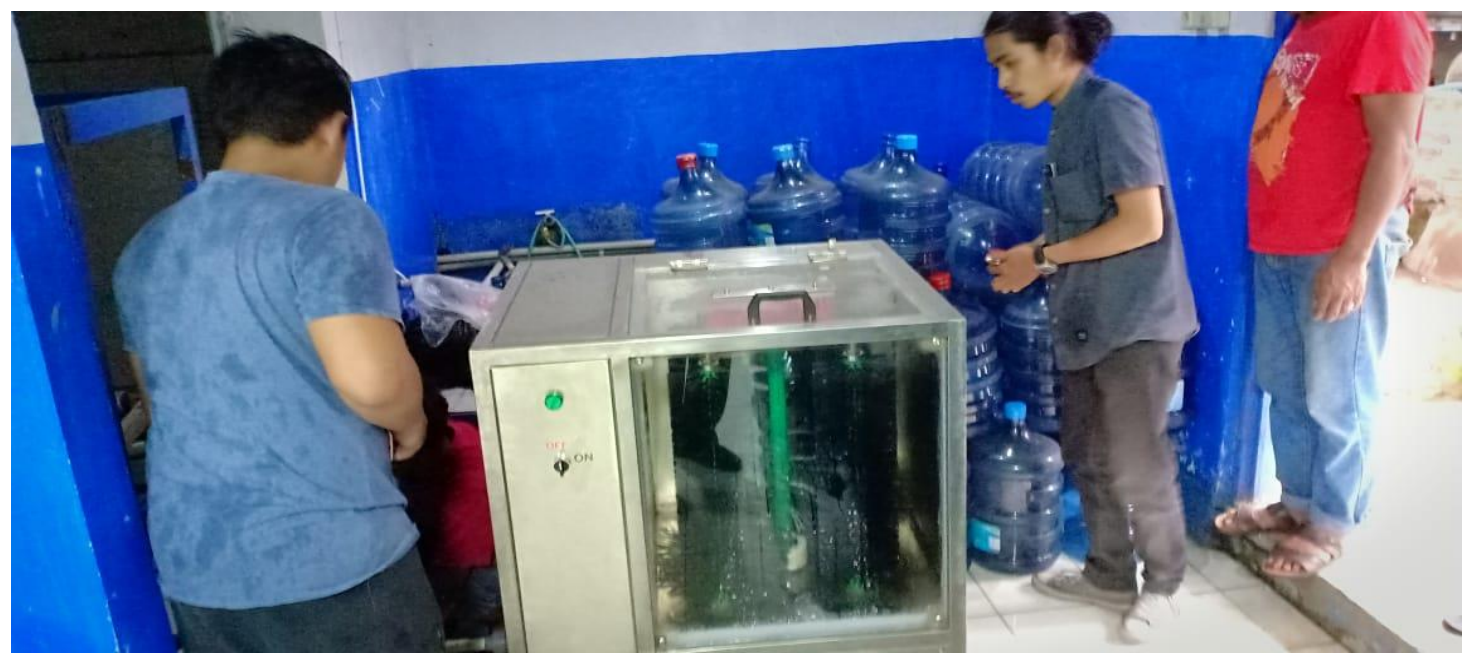

Gambar 1. Penempatan alat pencuci galon

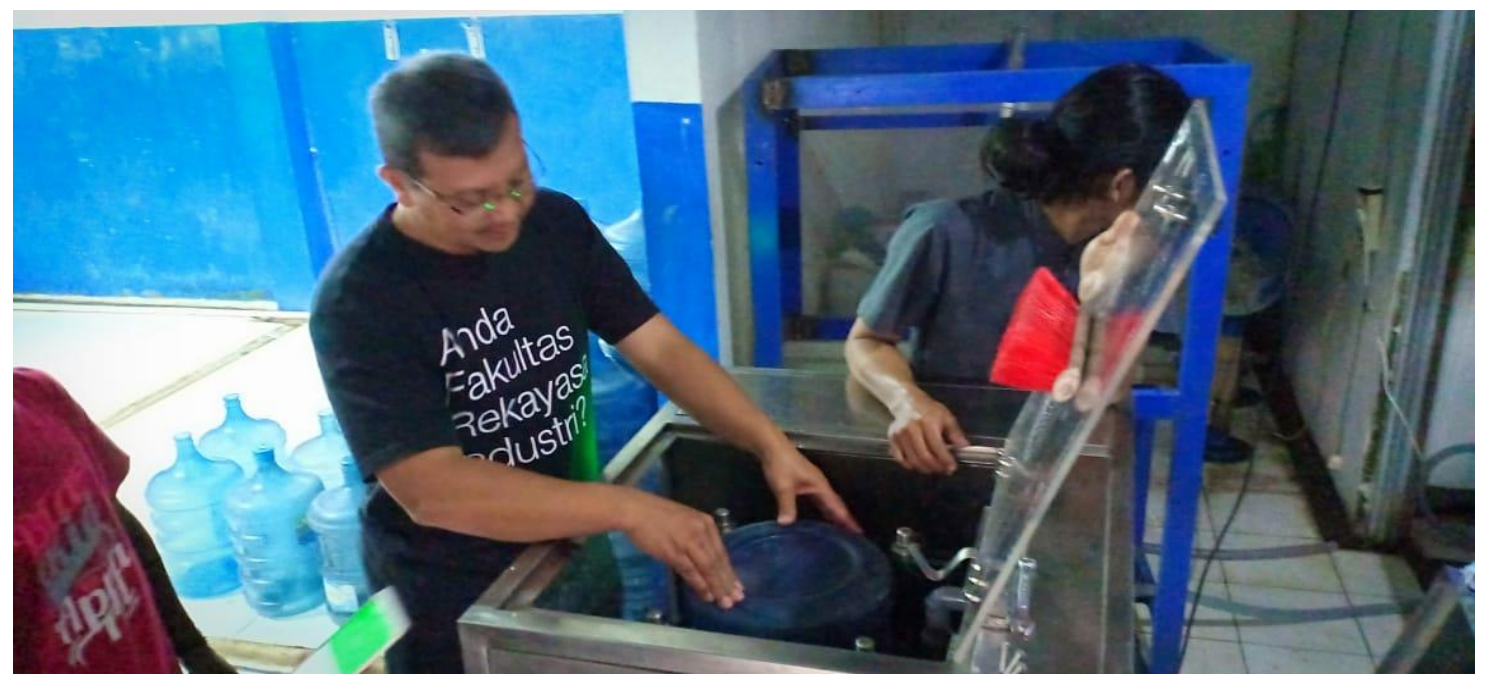

Gambar 2. Pelatihan penggunaan alat pencuci galon 


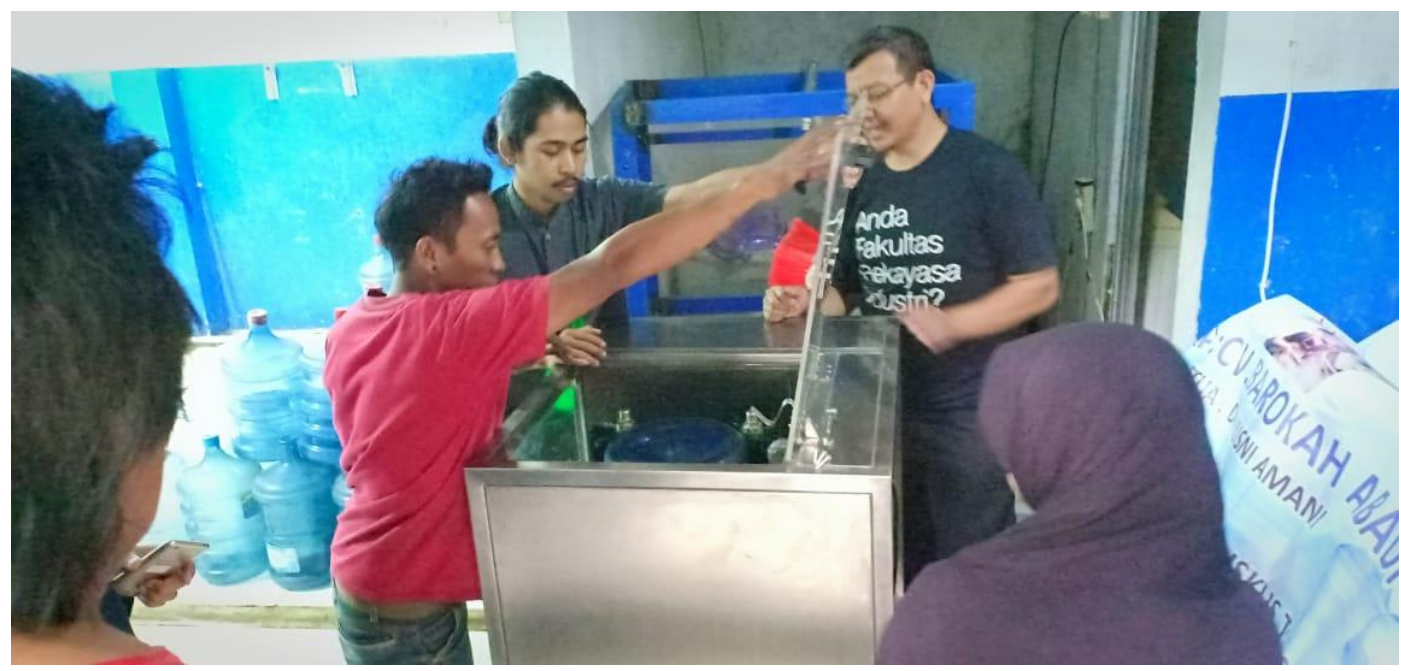

Gambar 3. Pelatihan penggunaan alat pencuci galon

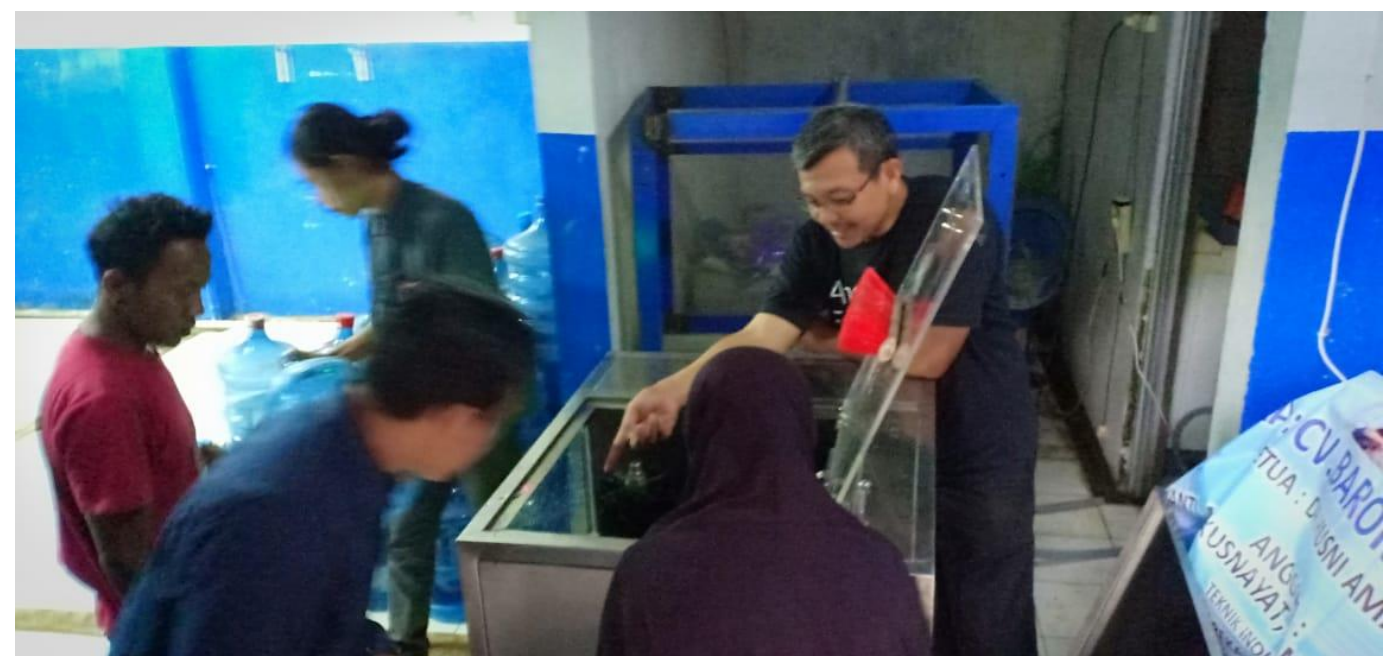

Gambar 4. Pelatihan penggunaan alat pencuci galon

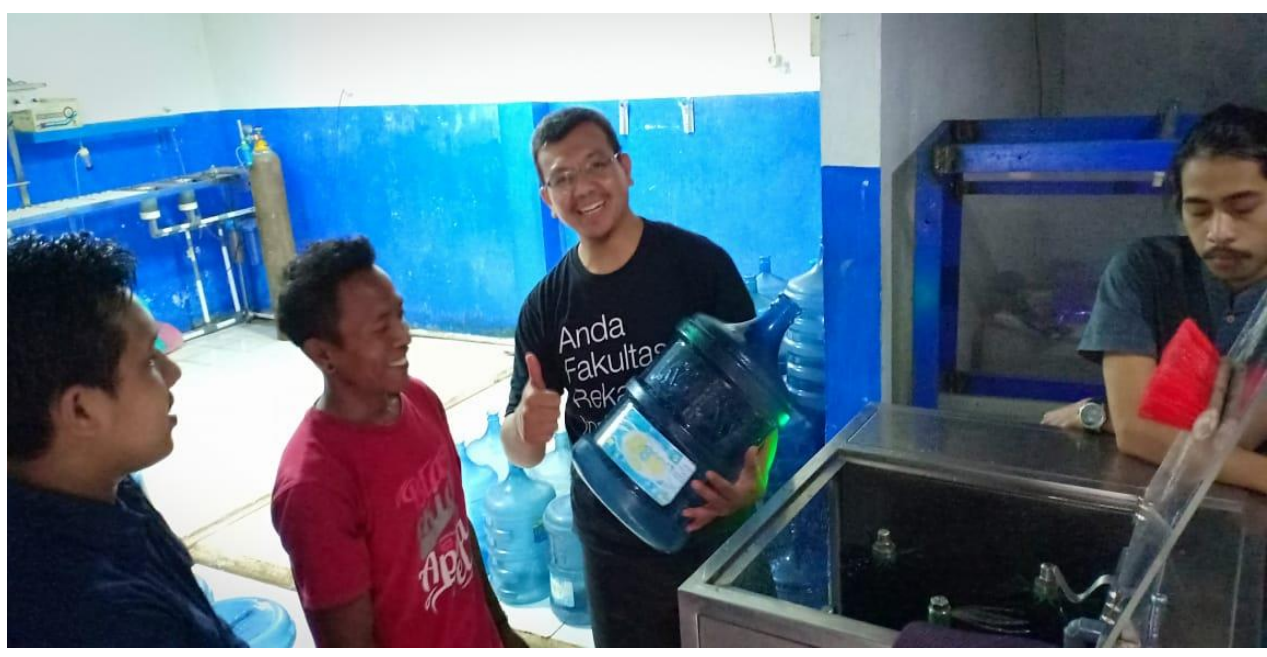

Gambar 5. Hasil pencucian menggunakan alat pencuci galon 


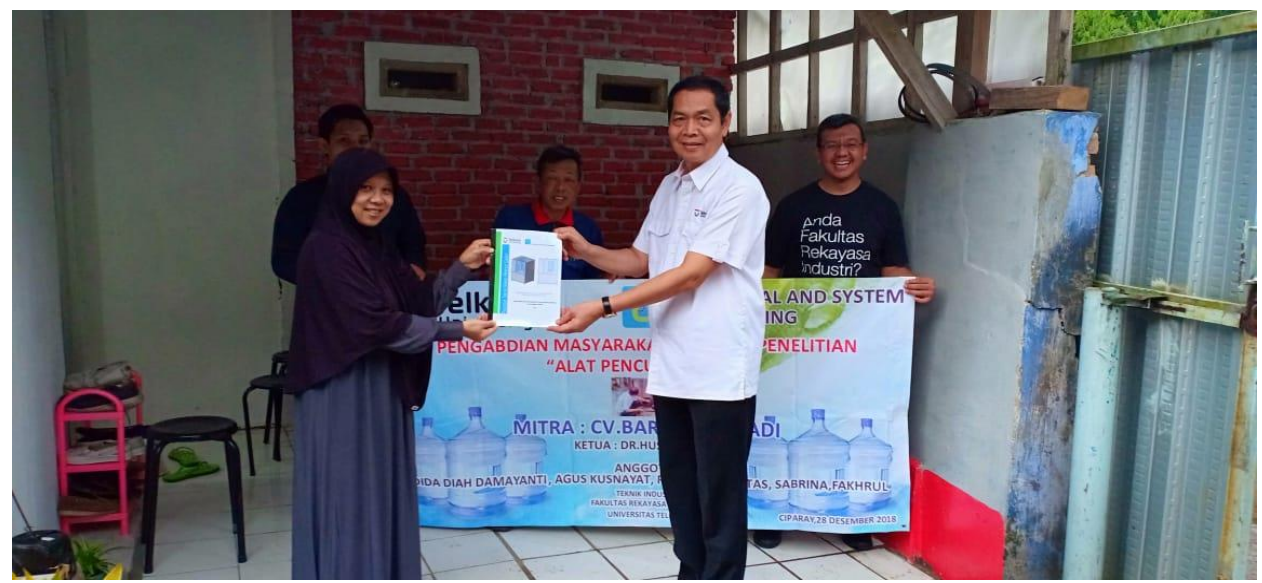

Gambar 6. Serah terima alat dan buku SOP (Standar Operational Procedure) alat pencuci galon

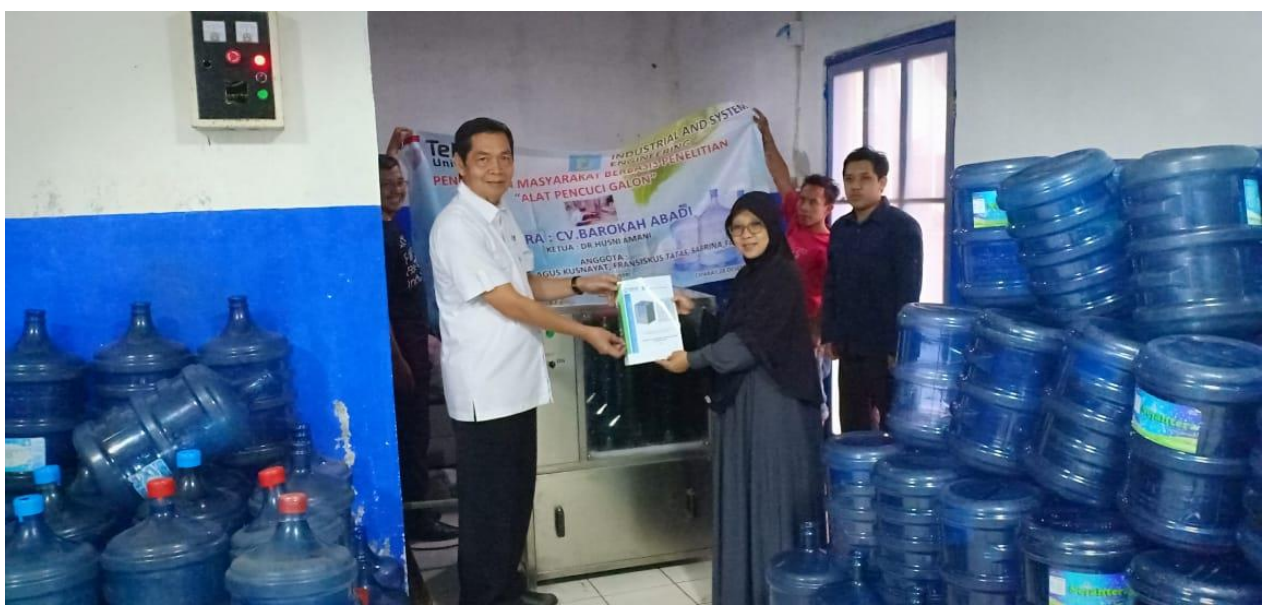

Gambar 7. Serah terima alat dan buku SOP (Standar Operational Procedure) alat pencuci galon

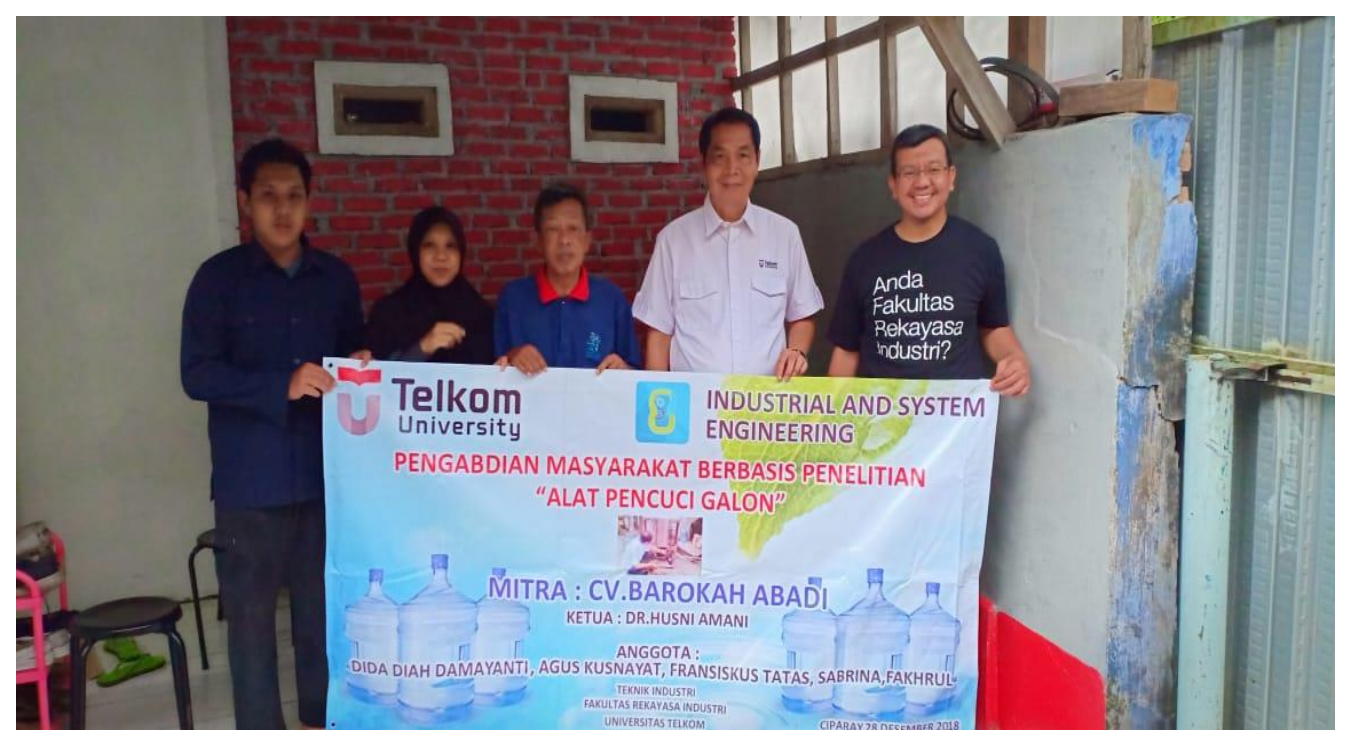

Gambar 8. Dokumentasi Pengabdian Masyarakat Berbasis Peneltian "Alat pencuci galon" 


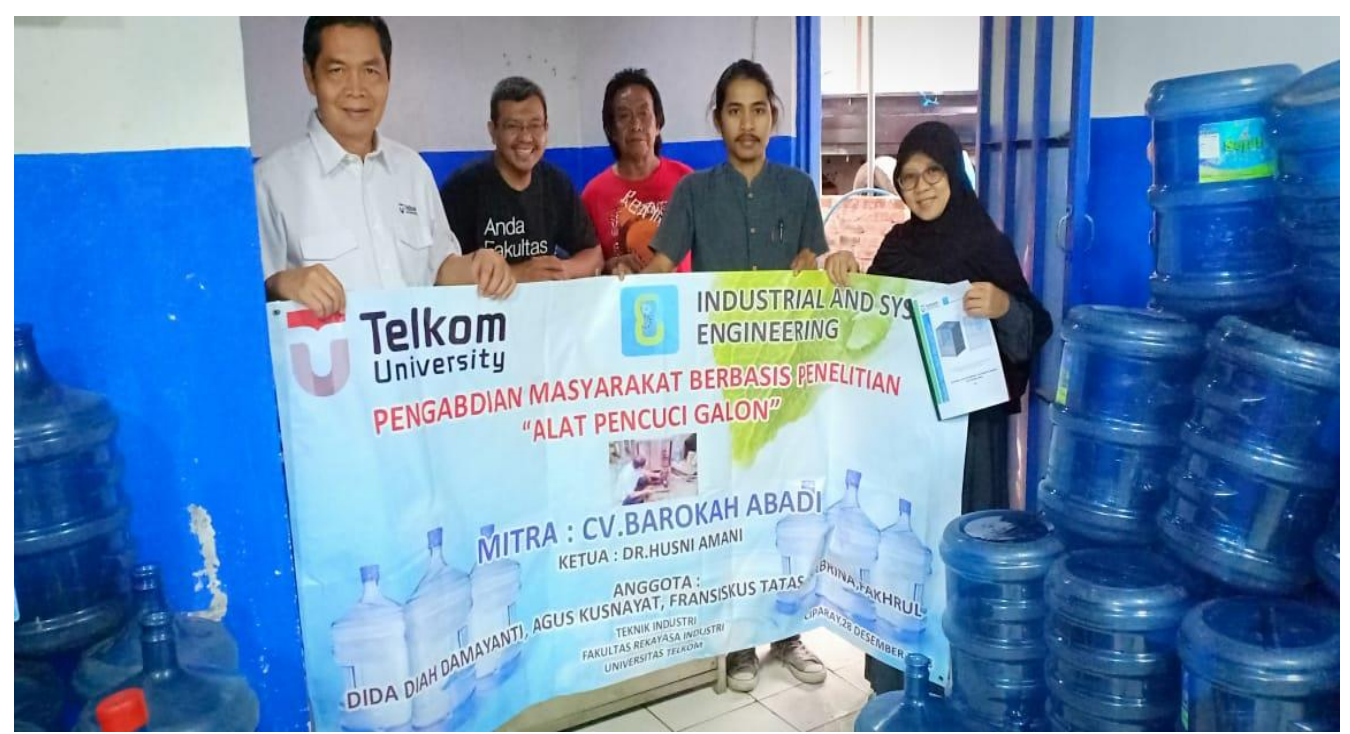

Gambar 9. Dokumentasi Pengabdian Masyarakat Berbasis Penelitian "Alat pencuci galon" 


\section{BIODATA/NARASI SINGKAT TEAM PENELITI:}

1. Dr.Ir. Husni Amani MSc.MBA adalah dosen tetap di Prodi S2 Teknik Industri. Gelar sarjana S1 dari TI ITB, S2 dari Prasetya Mulya Business School (MBA) dan Anglia Polytechnic University UK (Manajemen Sistem Telekomunikasi) dan S3 dari UNPAD. Penelitiannya dalam bidang Pemasaran, Produktifitas dan Bisnis ICT. Pernah bekerja di PT Telkom Indonesia di bidang logistic, projek digital, pengembangan materi training bidang manajemen telekomunikasi dan bisnis di Training Center dan Investor Relations. Penulis dapat dihubungi melalui email : husni@telkomuniversity.ac.id dan husni.amani@gmail.com

2. Agus Kusnayat, S.T., M.T. Lahir di Bandung 17 Agustus 1969. Ia menyelesaikan Sarjana Teknik di Fakultas Teknik Industri di Institut Sains dan Teknologi Nasional (ISTN) Jakarta tahun 1994 bidang Teknik Mesin . Pada tahun 1994-1998 menyelesaikan studi dibidang Dawah di STIA Al-Hikmah Jakarta. Tahun 2004 menyelesaikan studi Magister Teknik di Program Pascasarjana Universitas Indonesia (UI) di bidang Teknik Mesin. Pada tahun 2019 sedang menyelesaikan disertasi pendidikan Doktor Ilmu pendidikan UIN Bandung. Selepas selesai S1 diangkat menjadi Dsen Institut Sains dan Teknologi Nasional (1995-2016). Pernah mengajar di berbagai perguruan tinggi seperti Universitas Gunadarma Jakarta,STT Subang, STT Tekstil Bandung,Politeknik Telkom Bandung. Sejak Tahun (2016-Sekarang) mengajar full time di Universitas Telkom di prodi Teknik Industri Fakultas Rekayasa Industri. Adapun Mata kuliah yang diampu meliputi, Menggambar Teknik dan Praktikum, Mekanika Teknik,Material Teknik, Elemen Mesin,Proses Manufaktur, Perancangan Produk dan Proses Simultan,Penulisan Ilmiah. Penulis dapat dihubungi melalui email : guskus@telkomuniversity.ac.id , agus_kusnayat@yahoo.com serta aguskusnayat17@gmail.com

3. Dr.Dida Diah Damayanti meraih gelar Sarjana Teknik Industri pada tahun 1994 dari Institut Teknologi Bandung (ITB). Pada tahun itu pula bergabung pada Jurusan Teknik Industri STT Telkom sebagai dosen muda. Dida Diah Damayanti menyelesaikan Master of Engineering Science (M.Eng.Sc) in Manufacturing Engineering di New South Wales University, Australia pada tahun 1998. Pada tahun 2008, Dida Diah Damayanti menyelesaikan program doktoral dari program studi Teknik Industri di Institut Teknologi Bandung (ITB), dengan kajian penelitian pada area manufacturing system planning and design dan system optimization. Penulis dapat dihubungi melalui email : didadiah@telkomuniversity.ac.id dan didadiah@gmail.com

4. Fransiskus Tatas Dwi Atmaji, S.T., M.Eng adalah dosen tetap di prodi Teknik Industri, Fakultas Rekayasa Industri Universitas Telkom. Mengajar matakuliah Menggambar Teknik \& Praktikum, Material Teknik, Mekanika Teknik dan juga mata kuliah pilihan seperti Manajemen Perawatan Industri, Manajemen Aset Mesin dan Proposal Penelitian Ilmiah. Gelar Sarjana Teknik (S.T.) diperoleh dari Universitas Atma Jaya Yogyakarta (UAJY), Yogyakarta dan gelar Master of Engineering (M.Eng) di bidang Industrial \& System 
Engineering dari Dongguk University Seoul, Korea. Sebelum bergabung ke Universitas Telkom, Fransiskus Tatas Dwi Atmaji adalah praktisi di beberapa perusahaan seperti PT.Toyo Seal Indonesia, PT. Korindo (Korea), Daerim Communication Ltd (Korea), dan PT.Ceres-Bandung. Bidang penelitiannya adalah di bidang Industrial Engineering Maintenance, Reliability Engineering, dan Data Mining for Industrial Maintenance. Penulis dapat dihubungi melalui email : franstatas@telkomuniversity.ac.id dan frans.tatas@gmail.com 